\title{
Metabolism of Proinsulin, Insulin,
} and C-Peptide in the Rat

\author{
Adrian I. Katz and Arthur H. Rubenstein \\ From the Department of Medicine, University of Chicago Pritzker School of \\ Medicine, Chicago, Illinois 60637
}

A B S T R A C T The renal extraction and excretion of bovine proinsulin, insulin, and $\mathrm{C}$-peptide and the contribution of the kidney to their total metabolic clearance rate (MCR) were studied in the rat. Metabolic clearance rates were measured by the constant infusion technique and plasma and urine concentrations of each polypeptide were determined by radioimmunoassay.

The MCR of insulin $(16.4 \pm 0.4 \mathrm{ml} / \mathrm{min})$ was significantly greater than that of either proinsulin (6.7 $\pm 0.3 \mathrm{ml} / \mathrm{min})$ or C-peptide $(4.6 \pm 0.2 \mathrm{ml} / \mathrm{min})$. Metabolic clearance rates were independent of plasma levels over a range of steady-state plasma concentrations varying from 1 to $15 \mathrm{ng} / \mathrm{ml}$.

In contrast to the differences in their metabolic clearance rates, the renal disposition of the three polypeptides was similar, being characterized by high extraction and very low urinary clearance. The renal arteriovenous difference of proinsulin, insulin, and $\mathrm{C}$-peptide averaged 36,40 , and $44 \%$, respectively, and was linearly related to their arterial concentration between 2 and 25 $\mathrm{ng} / \mathrm{ml}$. When glomerular filtration was markedly reduced or stopped by ureteral obstruction, the renal extraction of proinsulin, insulin, and C-peptide was invariably greater than the simultaneously measured extraction of inulin, indicating that these polypeptides are removed from the renal circulation by both glomerular filtration and direct uptake from peritubular capillary blood. The fractional urinary clearance of each polypeptide never exceeded $0.6 \%$, indicating that more than $99 \%$ of the amount filtered was sequestered in the kidney.

The renal removal of proinsulin and C-peptide from the circulation accounts for 55 and $69 \%$ of their metabolic clearance rates, while the renal contribution to the peripheral metabolism of insulin was smaller, aver-

This work was published in abstract form in $1972 \mathrm{~J}$. Clin. Invest. $51: 49 \mathrm{a}$.

Received for publication 18 September 1972 and in revised form 13 December 1972. aging $33 \%$. This difference is due to the fact that insulin, but not the other two polypeptides, is metabolized to a significant extent by the liver. These results define the renal handling of proinsulin, insulin, and Cpeptide in the rat and indicate that in this species the kidney represents a major site for insulin metabolism and is the main organ responsible for the degradation of proinsulin and C-peptide.

\section{INTRODUCTION}

Differential secretion rates of insulin, proinsulin, and C-peptide by pancreatic beta cells have generally been considered to be the major determinant of their plasma concentrations (1-3). However, in vivo and in vitro studies have indicated that the peripheral distribution, metabolism, and degradation of insulin and proinsulin differ, suggesting that these factors may play an important role in determining their blood levels. Thus, the half disappearance time of proinsulin in dogs (4), swine (5), rats (6), and baboons (5) is two- to threefold longer than that of insulin. Experiments with the isolated perfused liver $(7,8)$ have shown a high clearance of insulin compared with the removal of proinsulin. Tissue homogenates (9) and specific proteases purified from liver, kidney, and skeletal muscle (10-13) degrade insulin at a significantly faster rate than proinsulin, and isolated liver plasma membranes (14) have a greater affinity for insulin compared with proinsulin. Nevertheless, the metabolic clearance rates of these polypeptides have not been measured under comparable experimental conditions, and there is as yet no information concerning the peripheral metabolism of C-peptide.

In the present study we measured the metabolic clearance rate $(\mathrm{MCR})^{1}$ of the unlabeled bovine proinsulin, insulin, and C-peptide in anesthetized rats by the constant infusion technique. As the kidney is probably the

\footnotetext{
${ }^{1}$ Abbreviations used in this paper: $\mathrm{A}_{\mathbf{P A B}}$, arterial concentration of $\mathrm{PAH} ; \mathrm{C}_{\mathrm{In}}$, clearance of inulin; $\mathrm{E}_{\mathbf{P A B}}, \mathrm{PAH}$ ex-
} 
most important organ involved in the removal of these polypeptides from the systemic circulation, the renal extraction and excretion of proinsulin, insulin, and C-peptide were studied under identical experimental conditions, and the contribution of the renal clearance of each polypeptide to its total metabolic clearance rate was assessed.

\section{METHODS}

Infusion studies. Male Sprague-Dawley rats $(300-420 \mathrm{~g})$ had free access to water and a pellet rat diet until surgery. Animals were anesthetized with Inactin (Promonta, Hamburg, West Germany) $120 \mathrm{mg} / \mathrm{kg}$ intraperitoneally, a tracheostomy was performed, and the bladder, a jugular vein, and one carotid artery were cannulated with polyethylene PE50 catheters. After exposure of the left renal vein, the adrenal and spermatic veins were ligated and the rats were placed on a heated animal board. Rectal temperature, monitored by a thermistor probe (Yellow Springs Instrument Co., Inc., Yellow Springs, Ohio), was maintained between $37^{\circ} \mathrm{C}$ and $38^{\circ} \mathrm{C}$. During surgery, isotonic saline equal to $0.5-1 \%$ of the body weight was infused intravenously to replace estimated fluid losses.

Following priming doses of $20 \mathrm{mg}$ inulin and $3 \mathrm{mg} \mathrm{p}$ aminohippurate $(\mathrm{PAH})$, a sustaining solution calculated to maintain plasma levels at approximately 50 and $3 \mathrm{mg} / 100$ $\mathrm{ml}$, respectively, was delivered with constant infusion pumps (Harvard Model 975; Harvard Apparatus Co., Inc., Millis, Mass.) at the rate of $40 \mu \mathrm{l} / \mathrm{min}$. Bovine proinsulin, insulin, and C-peptide were infused at different rates (15-100 ng/ $\min$ ) to obtain a wide range of steady-state plasma concentrations, as indicated in the Results section. Each polypeptide was infused separately, together with the infusion of inulin and PAH. After an equilibration period of $60 \mathrm{~min}$, urine was collected under mineral oil and volumes measured with glass micropipettes. In each experiment three to four consecutive collection periods of 30 min each were obtained, and arterial blood was drawn in heparinized capillary tubes before and after each collection period. After completion of urine collections, two arterial samples were drawn simultaneously with two renal venous blood samples at 15 -min intervals for measurement of $\mathrm{PAH}$ and polypeptide extraction. Renal venous blood was withdrawn slowly with gauge 29 needles into heparinized tuberculin syringes.

The renal handling of each polypeptide was further evaluated in experiments where glomerular filtration was markedly reduced by ureteral obstruction. Rats were anesthetized and infused as described above, but the left ureter was tied with double silk ligatures immediately after the priming injection. $2 \mathrm{~h}$ later, simultaneous samples were obtained from the renal vein of the obstructed kidney and from the carotid artery, and the renal extraction of each polypeptide was compared with that of inulin.

Additional studies were designed to evaluate the contribution of the kidneys to the metabolism of proinsulin, insulin, and $\mathrm{C}$-peptide. Both renal pedicles were exposed and double silk ligatures placed loosely around them. Each polypeptide was given by constant intravenous infusion, and after obtaining three to four base-line arterial samples, the renal

traction; ERPF, effective renal plasma flow; GFR, glomerular filtration rate; MCR, metabolic clearance rate; $\mathrm{PAH}, p$-aminohippurate; RPF, renal plasma flow; $\mathrm{RV}_{\mathrm{PAH}}$, renal venous concentration of $\mathrm{PAH}$. pedicles were tied and five additional blood samples were drawn at 15 -min intervals.

Materials. Bovine proinsulin and insulin were purified from first crystals of insulin (kindly supplied by the Novo Company, Copenhagen, Denmark) (15). Immunoassay of fractions after gel filtration showed less than $0.3 \%$ contamination of proinsulin with material eluting in the insulin region of the column, while the insulin was essentially free of early eluting components. C-peptide was isolated from bovine pancreas and purified by procedures which have been described previously (16). Solutions for the infusion experiments and immunoassay standards were made from the same batches of material. The infusate was prepared in isotonic saline from a stock solution of polypeptide $(400 \mu \mathrm{g} / \mathrm{ml})$ dissolved in tris-HCL buffer ( $\mathrm{pH} 7.4$ ) containing $1 \%$ bovine serum albumin to prevent loss by adsorption into glassware and polyethylene tubing. Polypeptide concentrations in the infusate were verified by measuring a portion together with the blood and urine samples from the same experiments.

Chemical and immunological methods. Glomerular filtration rate (GFR) and effective renal plasma flow (ERPF) were calculated from the clearance of inulin and $\mathrm{PAH}$, respectively. Plasma and urine concentrations of inulin and $\mathrm{PAH}$ were determined in duplicate samples by semimicro modifications of the anthrone (17) and diazotization (18) methods. Glucose was measured by the glucose oxidase method (19). The polypeptides were measured by a modification of the double antibody immunoassay of Morgan and Lazarow (20). Bovine [ $\left.{ }^{125} \mathrm{I}\right]$ proinsulin and a purified bovine proinsulin antiserum which did not cross react with rat insulin nor rat $\mathrm{C}$-peptide (and presumably rat proinsulin) at concentrations up to $20 \mathrm{ng} / \mathrm{ml}$ were used to assay bovine proinsulin. Bovine $\mathrm{C}$-peptide was measured using a bovine proinsulin antiserum and synthetic $\left[{ }^{125} \mathrm{I}\right]$ tyrosyllated bovine C-peptide (kindly supplied by Dr. N. Yaniahara). Rat insulin and C-peptide $(20 \mathrm{ng} / \mathrm{ml})$ did not cross-react in this assay system. The rat C-peptide (kindly supplied by Dr. $\mathrm{H}$. Tager) also did not compete with $\left[{ }^{125} \mathrm{I}\right]$ insulin in the insulin assay. Because bovine insulin, proinsulin, and C-peptide were infused in separate experiments, the individual assay characteristics described above ensured the specific measurement of each infused bovine polypeptide.

Gel filtration. Selected plasma samples $(0.1-0.5 \mathrm{ml})$ were gel filtered $(1,2)$ on $1 \times 50 \mathrm{~cm}$ columns of Biogel P-30 (Bio-Rad Laboratories, Richmond, Calif.) equilibrated in $3 \mathrm{M}$ acetic acid (C-peptide experiments) and borate albumin buffer, $\mathrm{pH} 8.2$ (insulin and proinsulin experiments). The columns were calibrated with $\left[{ }^{125} \mathrm{I}\right]$ proinsulin, $\left[{ }^{125} \mathrm{I}\right]$ insulin, and $\left[{ }^{125} \mathrm{I}\right]$ tyrosyllated $\mathrm{C}$-peptide. Portions of the column fractions from the experiments in which proinsulin was infused, were measured in the bovine proinsulin, C-peptide, and insulin assays. As bovine proinsulin and C-peptide reacted on an equimolar basis in the bovine proinsulin assay, degradation of proinsulin to C-peptide would have been readily detected by this method, as well as in the $\mathrm{C}$-peptide assay. Preliminary experiments (carried out in conjunction with Dr. Yaniahara) have demonstrated that certain synthetic fragments of bovine C-peptide do cross-react in the bovine $\mathrm{C}$-peptide immunoassay system. If the infused bovine C-peptide, or proinsulin were degraded to these smaller fragments in the circulation, material reacting in the $\mathrm{C}$ peptide assay should have been detected in column fractions eluting later than the intact C-peptide.

Calculations. Urinary clearances of each polypeptide and of inulin and $\mathrm{PAH}$ were calculated from their respective urine: plasma concentration ratios and the urine flow by standard formulas. PAH extraction $\left(E_{P A B}\right)$ was calculated 
from the arterial ( $\left.A_{P A H}\right)$ and renal venous $\left(R V_{P A H}\right)$ concentrations of PAH :

$$
\mathrm{E}_{\mathrm{PAH}}=\frac{\mathrm{A}_{\mathrm{PAH}}-\mathrm{R} V_{\mathrm{PAH}}}{\mathrm{A}_{\mathrm{PAH}}} \times 100,
$$

and renal plasma flow (RPF) from the ratio of $\mathrm{PAH}$ clearance $\left(\mathrm{C}_{\mathrm{PAH}}\right)$ to $\mathrm{PAH}$ extraction:

$$
\mathrm{RPF}=\mathrm{C}_{\mathrm{PAH}} / \mathrm{E}_{\mathrm{PAH}} \times 100 .
$$

Extraction of proinsulin, insulin, and C-peptide was derived from concentrations in arterial and renal venous samples analogous to the extraction of PAH. Renal clearance ${ }^{2}$ of these polypeptides was estimated from the product of their respective extraction rates and the renal plasma flow, and expressed in milliliters per minute. Metabolic clearance rates measured by the constant infusion technique (21) were calculated by dividing the infusion rate by the steady-state plasma concentrations:

$$
\mathrm{MCR}=\text { infusion rate/plasma concentration. }
$$

Results are presented as mean \pm 1 SEM. Regression lines were calculated by the method of least squares. Statistical significance was assessed by Student's $t$ test and $P$ values less than 0.05 were considered significant.

\section{RESULTS}

Preliminary experiments. A number of preliminary experiments were performed to validate the methods used in this study. First, because rat insulin crossreacts in the bovine insulin assay, the minimal concentration of the hormone capable of lowering plasma glucose to levels which do not stimulate endogenous insulin release was determined. The initial plasma glucose in seven rats was $119 \pm 4 \mathrm{mg} / 100 \mathrm{ml}$. After administration of a priming dose of $500 \mathrm{ng}$ insulin, a sustaining infusion of $30 \mathrm{ng} / \mathrm{min}$-the lowest infusate concentration used in subsequent experiments-was started. After the $60 \mathrm{~min}$ equilibration period, plasma glucose had fallen to $53 \pm 4 \mathrm{mg} / 100 \mathrm{ml}$ and remained low for the subsequent $2 \mathrm{~h}$ when plasma samples for estimation of the MCR were obtained $(53 \pm 2 \mathrm{mg} / 100 \mathrm{ml}$ at $120 \mathrm{~min}$ and $37 \pm 3 \mathrm{mg} / 100 \mathrm{ml}$ at $180 \mathrm{~min})$. As the circulating insulin of 24-h fasted rats with a mean plasma glucose of $65 \mathrm{mg} / 100 \mathrm{ml}$ was only $0.2 \mathrm{ng} / \mathrm{ml}$, we concluded that the interference from endogenous insulin at glucose levels of $53 \mathrm{mg} / 100 \mathrm{ml}$ or less would be negligible. Although it is appreciated that the insulin experiments were performed in mildly hypoglycemic animals, the need to suppress endogenous insulin release necessitated this approach.

At the termination of each experiment, rats were exsanguinated to obtain sufficient plasma for dilution

\footnotetext{
${ }^{2}$ Throughout this study renal clearance denotes milliliters of plasma cleared of each polypeptide by the kidney in $1 \mathrm{~min}$ and should not be confused with the urinary clearance which represents only the negligible fraction of the former that can be accounted for by urinary excretion.
}

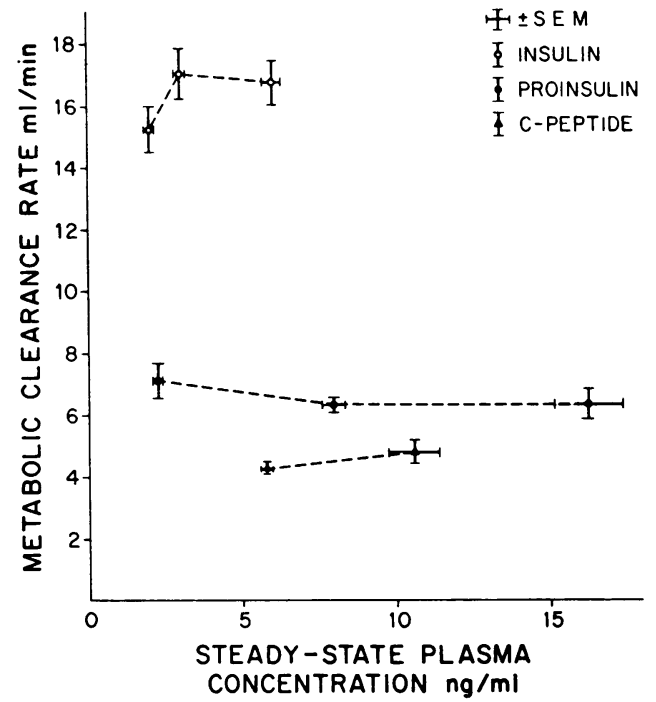

Figure 1 Metabolic clearance rates of insulin ( $O$ ), proinsulin ( $\bullet$, and C-peptide ( $\boldsymbol{\Delta})$. MCR's of each polypeptide were similar over a wide range of steady-state plasma concentrations.

studies and, in selected samples, for column fractionation. Plasma portions varying from 25 to $250 \mu$ l gave similar values when calculated from the appropriate bovine peptide standard and corrected for the quantity assayed. Recovery of bovine insulin, proinsulin, and C-peptide (1.0-4.0 ng) added to rat urine and plasma ranged between 94 and $102 \%$. Plasma specimens showed single immunologically identifiable peaks in their expected position after gel filtration. Specifically, we were unable to show small molecular weight fragments of bovine C-peptide eluting from the column in a position later than the intact $\mathrm{C}$-peptide. In order to detect possible conversion of proinsulin to insulin and C-peptide (22), column fractions from the proinsulin experiments were also assayed in the insulin and C-peptide systems. No conversion to these polypeptides could be demonstrated. The total quantity of polypeptide recovered after gel filtration (82-98\%) corresponded closely to the direct assay result.

Metabolic clearance rates. The mean metabolic clearance rate of insulin $(16.4 \pm 0.4 \mathrm{ml} / \mathrm{min})$ was significantly $(P<0.001)$ greater than that of either proinsulin $(6.7$ $\pm 0.3 \mathrm{ml} / \mathrm{min}$ ) or C-peptide $(4.6 \pm 0.2 \mathrm{ml} / \mathrm{min}$ ) (Table I). The difference between the MCR of proinsulin and $\mathrm{C}$-peptide was also significant $(P<0.001)$. The metabolic clearance rates were independent of plasma levels (Fig. 1) over a range of steady-state plasma concentrations varying from less than 2 to more than 15 $\mathrm{ng} / \mathrm{ml}$.

Renal extraction and excretion. In contrast to the total metabolic clearance rate, the renal disposition of proinsulin, insulin, and $\mathrm{C}$-peptide was similar, being 


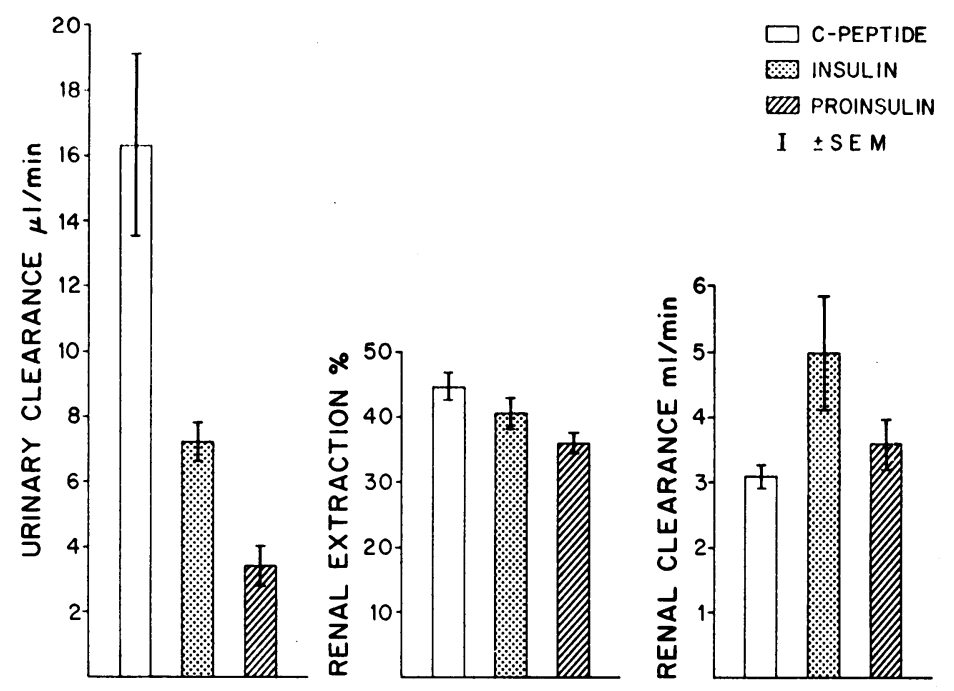

FIGURE 2 Urinary clearance, renal arteriovenous concentration difference, and renal clearance of C-peptide, insulin, and proinsulin.

characterized by high extraction and very low urinary clearance rates (Table I). Both the renal extraction and the urinary clearance were highest for C-peptide and lowest for proinsulin, with insulin occupying an intermediate position (Fig. 2). The renal arteriovenous difference of each polypeptide ranged between 36 and $44 \%$. However, their fractional urinary excretion (peptide clearance/inulin clearance $\times 100$ ) averages less than $0.6 \%$, indicating that more than $99 \%$ of the proinsulin, insulin, and C-peptide filtered was sequestered in the renal tubular cells.

The renal extraction of proinsulin, insulin, and Cpeptide was linearly related to their concentration in arterial blood between 2 and $25 \mathrm{ng} / \mathrm{ml}$ (Fig. 3). Thus, there was no evidence of saturation of the renal extraction process of any of the three polypeptides even at concentrations well in excess of those usually found in the postabsorptive state or after pancreatic stimulation by pharmacological agents.

In order to evaluate the contribution of the renal clearance of proinsulin, insulin, and C-peptide to their total MCR, we analyzed separately the results from those rats in which measurements of glomerular filtration rate, renal plasma flow, and renal extraction and MCR of the respective polypeptide were made in the same clearance period (Table II). The renal clearances of proinsulin, insulin, and C-peptide, estimated from the renal plasma flow and renal arteriovenous difference, ranged between 3 and $5 \mathrm{ml} / \mathrm{min}$ and were not significantly different from each other. Nevertheless, their contribution to the respective total metabolic clearance rate was markedly different due to the large differences between the MCR of insulin on the one hand, and the MCR of proinsulin and C-peptide on the other. Thus, while the renal clearance of proinsulin and C-peptide accounted for $55 \%$ and $69 \%$ of their respective $\mathrm{MCR}$, the renal contribution to the peripheral metabolism of insulin was much smaller, averaging only $33 \%$ of its total metabolic clearance rate (Fig. 4).

In the above experiments the mean renal clearance of proinsulin and insulin was similar to the glomerular filtration rate as measured by the clearance of inulin. The mean renal clearance of C-peptide, however, exceeded that of inulin $(P<0.001)$ suggesting that this

TABLE I

Metabolic Clearance Rate, Renal Extraction, and Urinary Clearance of Proinsulin, Insulin, and C-peptide

\begin{tabular}{|c|c|c|c|c|c|c|c|c|c|}
\hline Peptide & No. & $\begin{array}{c}\text { Body } \\
\text { weight }\end{array}$ & UV & $\mathrm{C}_{\text {In }}$ & $\mathrm{C}_{\mathrm{PAH}}$ & $\begin{array}{l}\text { Urinary } \\
\text { clearance }\end{array}$ & $\begin{array}{l}\text { Fractional } \\
\text { clearance }\end{array}$ & $\begin{array}{c}\text { Renal } \\
\text { extraction }\end{array}$ & MCR \\
\hline & & $g$ & $\mu l / \min$ & $\mathrm{ml} / \mathrm{min}$ & $m l / m i n$ & $\mu l / \min$ & $\%$ & $\%$ & $\mathrm{ml} / \mathrm{min}$ \\
\hline Proinsulin & 36 & $363 \pm 5$ & $14.9 \pm 2.4$ & $3.25 \pm 0.16$ & $7.80 \pm 0.36$ & $3.4 \pm 0.6$ & $0.11 \pm 0.02$ & $36.0 \pm 1.4$ & $6.68 \pm 0.28$ \\
\hline Insulin & 30 & $343 \pm 4$ & $15.9 \pm 2.5$ & $4.34 \pm 0.17$ & $9.57 \pm 0.87$ & $7.2 \pm 0.6$ & $0.20 \pm 0.03$ & $40.5 \pm 2.0$ & $16.38 \pm 0.43$ \\
\hline C-peptide & 27 & $349 \pm 7$ & $8.4 \pm 0.4$ & $2.91 \pm 0.10$ & $6.22 \pm 0.22$ & $16.3 \pm 2.8$ & $0.57 \pm 0.09$ & $44.5 \pm 2.0$ & $4.56 \pm 0.20$ \\
\hline
\end{tabular}

$\mathrm{C}_{\mathrm{In}}$, clearance of inulin; $\mathrm{UV}$, urine flow. 


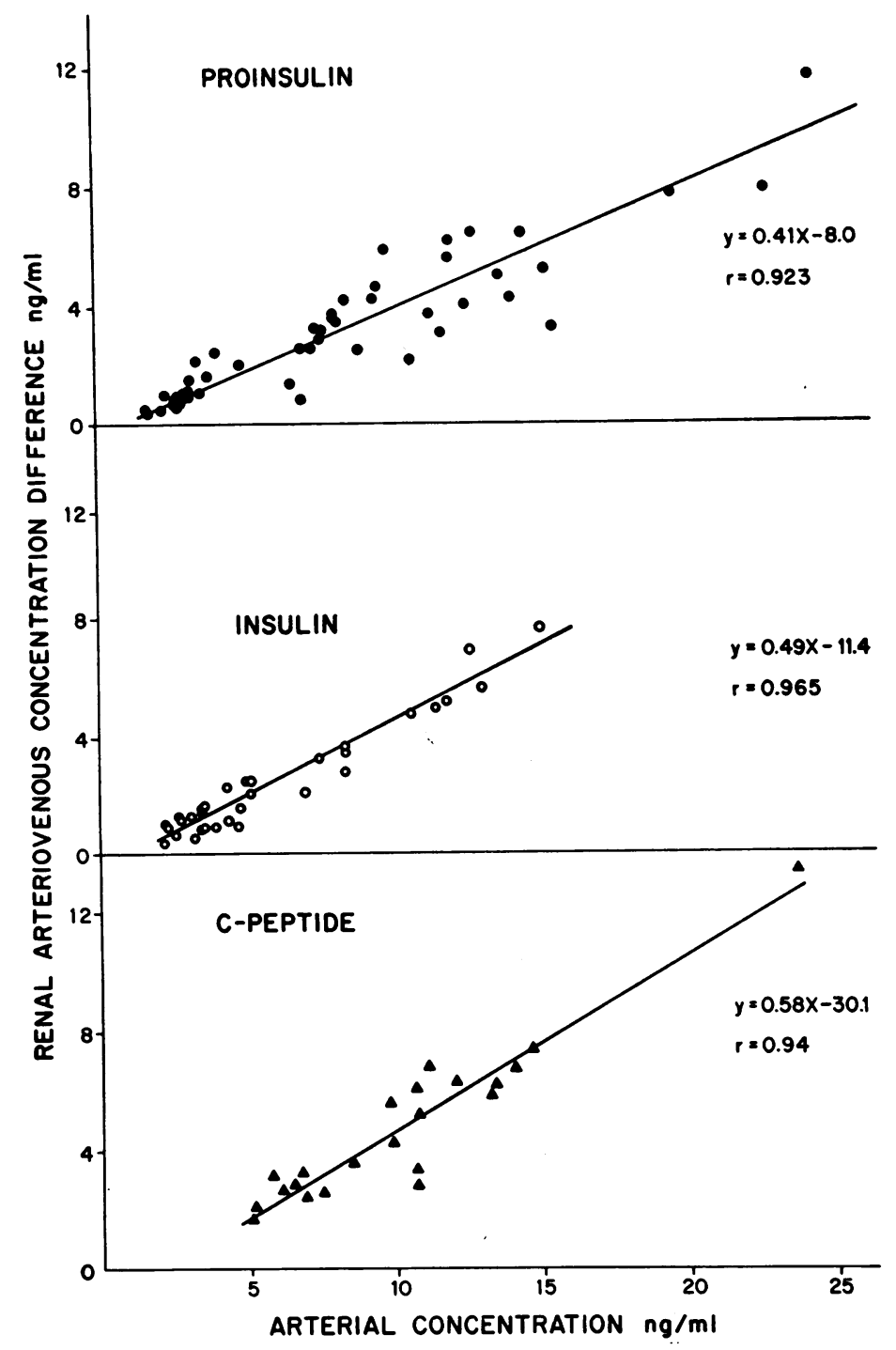

FIGURE 3 Relation of renal arteriovenous concentration difference of proinsulin, insulin, and C-peptide to their respective arterial concentrations.

polypeptide was extracted in part from postglomerular plasma. Results from individual experiments revealed that proinsulin clearance was higher than that of inulin in four of nine animals and the insulin clearance ex- ceeded the clearance of inulin in four of eight rats. By contrast, the renal clearance of $\mathrm{C}$-peptide was higher than the clearance of inulin in each of the eight animals tested.

TABLE II

Contribution of the Renal Clearances of Proinsulin, Insulin, and C-peptide to their Metabolic Clearance Rates

\begin{tabular}{|c|c|c|c|c|c|c|c|c|c|}
\hline Peptide & No. & $\mathrm{C}_{\text {In }}$ & $\mathrm{C}_{\mathrm{PAH}}$ & $\mathrm{E}_{\mathrm{PAH}}$ & RPF & $\begin{array}{c}\text { Renal } \\
\text { extraction }\end{array}$ & $\begin{array}{c}\text { Renal } \\
\text { clearance }\end{array}$ & MCR & $\begin{array}{c}\text { Renal } \\
\text { clearance/MCR }\end{array}$ \\
\hline & & $\mathrm{ml} / \mathrm{min}$ & $\mathrm{ml} / \min$ & $\%$ & $\mathrm{ml} / \mathrm{min}$ & $\%$ & $\mathrm{ml} / \mathrm{min}$ & $\mathrm{ml} / \min$ & $\%$ \\
\hline Proinsulin & 9 & $3.23 \pm 0.21$ & $7.65 \pm 0.51$ & $82.0 \pm 1.4$ & $9.33 \pm 0.61$ & $38.1 \pm 2.9$ & $3.57 \pm 0.39$ & $6.57 \pm 0.15$ & $54.9 \pm 6.3$ \\
\hline Insulin & 8 & $4.36 \pm 0.22$ & $9.94 \pm 0.90$ & $76.9 \pm 1.7$ & $12.92 \pm 1.13$ & $37.3 \pm 3.8$ & $5.00 \pm 0.88$ & $15.15 \pm 0.46$ & $33.3 \pm 4.4$ \\
\hline C-peptide & 8 & $2.60 \pm 0.09$ & $5.83 \pm 0.22$ & $78.3 \pm 2.2$ & $7.51 \pm 0.43$ & $41.6 \pm 2.0$ & $3.10 \pm 0.18$ & $4.57 \pm 0.27$ & $69.4 \pm 5.0$ \\
\hline
\end{tabular}




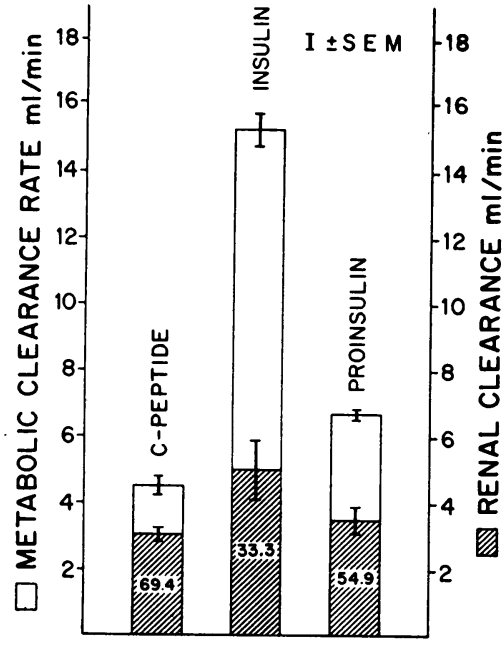

Figure 4 Renal clearance and metabolic clearance rate of $\mathrm{C}$-peptide, insulin, and proinsulin. Although the renal clearance of the three polypeptides was similar, its contribution to the total MCR (figures in cross-hatched areas) varied.

To clarify the mechanism whereby proinsulin, insulin, and C-peptide are removed by the kidneys from the circulation, the renal extraction of each polypeptide was compared to the extraction of inulin in kidneys in which the ureter was tied off (Table III). Inulin extraction stopped in approximately one-half of the animals, and ranged between 1.1 and $13.3 \%$ in the remainder. The extraction of each polypeptide was invariably greater than the corresponding extraction of inulin, and the differences between mean values were highly significant.

The role of the kidney in the metabolism of circulating proinsulin, insulin, and $\mathrm{C}$-peptide was also evalu-

TABLE III

Renal Extraction of Proinsulin, Insulin, and C-peptide Compared with the Extraction of Inulin after Reduction of GFR by Ureteral Obstruction

\begin{tabular}{lcc}
\hline & No. & $\begin{array}{c}\text { Renal arteriovenous } \\
\text { concentration } \\
\text { difference }\end{array}$ \\
\hline Proinsulin & & $\%$ \\
Inulin & 10 & $16.7 \pm 2.3$ \\
$P$ & & $1.8 \pm 1.2$ \\
Insulin & & $<0.001$ \\
Inulin & 8 & $19.9 \pm 3.9$ \\
$P$ & & $6.7 \pm 2.0$ \\
C-peptide & & $<0.005$ \\
Inulin & 10 & $20.3 \pm 3.8$ \\
$P$ & & $4.8 \pm 1.6$ \\
& & $<0.005$ \\
\hline
\end{tabular}

ated by another approach. In these studies the arterial plasma levels of each polypeptide were measured during constant infusion before and after exclusion of the kidneys from the circulation. Results of experiments in which proinsulin, insulin, and C-peptide were infused in approximately equimolar amounts $(5 \mathrm{pmol} / \mathrm{min})$ are illustrated in Fig. 5. After ligation of both renal pedicles, plasma insulin levels rose approximately $75 \%$ and rapidly reached a new steady state. By contrast, the average increase in the circulating levels of proinsulin and C-peptide was approximately threefold, and their concentrations continued to rise for longer periods of time after renal pedicle ligation. Essentially identical results were obtained in additional experiments using different infusion rates for each polypeptide (Fig. 6).

\section{DISCUSSION}

The metabolism, distribution, and half disappearance time of insulin has been studied in man and animals following the rapid injection of both the labeled and unlabeled hormone (23-26). The problems inherent in this approach have been pointed out by Corvilain et al. (27) and the potential advantage of the constant infusion technique for the measurement of the metabolic clearance rate of insulin has been discussed. Because of the possibility that even lightly iodinated insulin may not be metabolized identically to the native hormone (28), unlabeled polypeptides were infused in the present experiments.

The MCR of insulin varies in different species even when corrected for their body size. Thus Ooms et al. reported a value of $400 \mathrm{ml} / \mathrm{min}$ in dogs weighing 19-35 $\mathrm{kg}$ (28), while Swenson and his colleagues (29) determined that the irreversible loss rate of insulin from the plasma compartment of dogs weighing $14-24 \mathrm{~kg}$ was $1798 \mu \mathrm{U} / \mathrm{min}$ at a mean plasma level of $19 \mu \mathrm{U} / \mathrm{ml}$. Tompkins, Srivastava, Sonksen, and Nabarro (30) found that the MCR of insulin ranged from 9.7 to 17.8 $\mathrm{ml} / \mathrm{kg}$ per min in man, but a much lower value of 5.6 $\mathrm{ml} / \mathrm{kg}$ per min in fasting control subjects was obtained by Corvilain et al. (27). As expected, the metabolic clearance rate of insulin measured in rats in the present experiments $(45-50 \mathrm{ml} / \mathrm{kg}$ per $\mathrm{min})$ was more rapid when compared with the values in larger mammals. Moreover, in contrast to the results obtained with insulin in man (30) and dog (28), there was no decline in the MCR as the blood polypeptide levels increased within the physiological range.

Although it would have been preferable to use the homologous species of polypeptide, this was not possible due to the limited availability of rat C-peptide and proinsulin. Nevertheless, the difference between the metabolic clearance rates of bovine proinsulin and insulin observed in rats is comparable to data derived 
from similar experiments in other species. The immunological half-life of porcine proinsulin was 18 and 20 min and that of insulin 8 and 6 min in baboons and swine, respectively (5). Similar values were found after the injection of bovine proinsulin and insulin in dogs (4). Tompkins et al. (30) infused porcine insulin and proinsulin into healthy subjects and showed a mean MCR of $13.3 \mathrm{ml} / \mathrm{kg}$ per min for insulin and 3.1 $\mathrm{ml} / \mathrm{kg}$ per $\min$ for proinsulin, with mean half-lives of 4.4 and $25.6 \mathrm{~min}$, respectively. Finally, the half disappearance time of endogenous proinsulin (18-25 $\mathrm{min}$ ) was markedly slower than that of insulin (3-4 $\mathrm{min})$ in three patients following removal of their islet cell tumors (31). There is, as yet, no information concerning the metabolism of circulating C-peptide in intact animals, although Stoll, Touber, Menahan, and Williams (7) demonstrated that the porcine peptide was not taken up by the isolated perfused rat liver. The present experiments in anesthetized rats indicate that the metabolic clearance rate of $\mathrm{C}$-peptide is the slowest of the three polypeptides studied, and, like the MCR of proinsulin and insulin, was independent of plasma concentrations. Although there is no obvious reason to believe that anesthesia would have modified these results, its specific effects on the parameters studied were not investigated.

The renal handling of proinsulin, insulin, and C-peptide was characterized by high extraction rates and very low urinary clearances, indicating that almost all the polypeptide removed from the circulation was sequestered or metabolized in the kidney. Kidney homogenates are known to destroy insulin in vitro $(11,32)$, and autoradiographic studies in the rat show that labeled insulin accumulates in the cells of the proximal convoluted tubules $(33,34)$, where it presumably undergoes degradation. It is of interest that other small molecular weight polypeptides are handled by the kidney in similar fashion. Thus, high renal arteriovenous concentration differences and low urinary excretion rates of parathyroid hormone (35), gastrin (36), $\beta_{2}$-microglobulin (37), and angiotensin (38) have been reported in several species.

The mean renal arteriovenous difference of insulin was $40 \%$, which is in good agreement with values of $29 \%$ (39) and 39\% (40) reported in man and of $41 \%$ in the dog (41). The renal extraction of insulin in the rat was proportional to its arterial concentration in the range between 1 and $15 \mathrm{ng} / \mathrm{ml}$, the latter value exceeding physiological levels in the fed state. A similar linear relationship between the extraction of insulin and its arterial level was also found in dogs (41) and man $(39,40)$. The renal extraction of proinsulin and C-peptide in the present experiments was also linearly related to their arterial plasma concentrations up to levels of $25 \mathrm{ing} / \mathrm{ml}$. It appears therefore that the renal

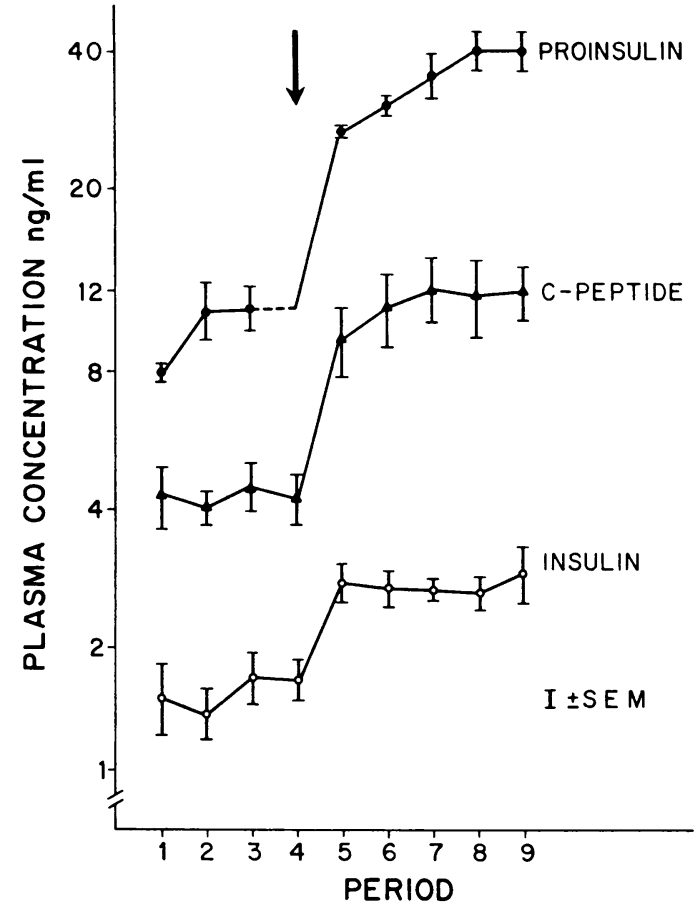

FigLRE 5 Effect of exclusion of the kidneys from the circulation on the circulating levels of proinsulin, insulin, and C-peptide. Periods 1-4 preceded, and periods 5-9 followed ligation of both renal pedicles (arrow).

extraction of all three polypeptides in the rat does not become saturated even at circulating levels well in excess of the physiological range. This contrasts with the extraction pattern by the other major metabolic organ, the liver, where the percentage removal of insulin decreases at high plasma concentrations (8).

The observation of renal arteriovenous concentration differences in excess of the usual filtration fraction in

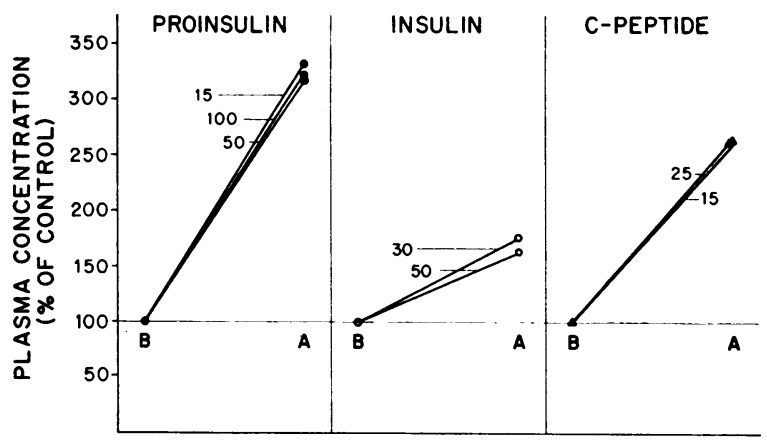

Figure 6 Effect of exclusion of the kidneys from the circulation on the circulating levels of proinsulin, insulin, and C-peptide. The relative increase in plasma levels of each polypeptide after ligation of the renal pedicles was similar at different infusion rates. $B$ represents the mean value for all periods before, and $A$ after renal pedicle ligation. Figures represent infusion rates in nanograms per minute. 
normal subjects (39) and dogs (42) has been adduced as evidence that in these species, insulin is cleared by direct tubular uptake from the postglomerular capillaries in addition to glomerular filtration. The extraction rates observed in the present study would suggest that in the rat, insulin, as well as proinsulin and $\mathrm{C}$-peptide, are also cleared by these two processes. This conclusion cannot be reached, however, on the basis of magnitude of renal extraction alone, since the filtration fraction in the rat is higher than in dog and man, and frequently exceeds 0.40 . We therefore evaluated the mechanism of polypeptide extraction by a more direct approach in which the arteriovenous concentration difference of each polypeptide and of inulin were measured simultaneously in kidneys in which the glomerular filtration was stopped or markedly reduced by ureteral obstruction (Table III). Substantial renal extraction of proinsulin, insulin, and C-peptide continued even when the extraction of inulin was abolished and thus glomerular filtration had stopped. This observation provides convincing evidence for the occurrence of direct tubular uptake of all three polypeptides in the rat.

The fractional urinary clearance of insulin averaged $0.2 \%$ which was considerably smaller than that found in the dog (about 10\%) (41), but similar to the values reported in normal man $(39,40,43)$. The urinary clearance of insulin was significantly less than that of C-peptide, but was greater than that of proinsulin (Fig. 2), suggesting an inverse relationship with the molecular weight of these polypeptides. The meaning of this observation is not clear since substances with molecular weight in the range of $3000-9000^{3}$ should be readily filterable through the glomerular barrier (45).

The renal clearance of insulin represented one-third of its total metabolic clearance rate whereas the renal contribution to the peripheral metabolism of proinsulin and $\mathrm{C}$-peptide was considerably higher, averaging approximately two-thirds of their respective MCR (Fig. 4 ). The results were comparable, whether based on the simultaneous determination of renal clearance and MCR or on the measurement of metabolic clearance rates before and after exclusion of the kidneys from the circulation. Since the renal clearance of all three polypeptides was similar, its variable contribution to their total MCR is explained by the difference between the MCR of insulin on the one hand and that of proinsulin and C-peptide on the other. As discussed above, this difference is probably due to the fact that insulin, but not the other polypeptides, is metabolized to a significant extent by the liver. The results also suggest that

${ }^{3}$ The approximate molecular weight of C-peptide, insulin, and proinsulin is 3000,6000 , and 9000 , respectively. They are believed to be present in the circulation in their monomeric form, and not bound to other plasma proteins (44). circulating concentrations of these polypeptides might be elevated in patients with renal failure, and our preliminary experiments are consistent with this possibility.

\section{ACKNOWLEDGMENTS}

The authors gratefully acknowledge the excellent technical assistance of Ms. Mary Mako, Barbara Corsaw-Hausler, and Margaret Lorincz. Dr. Marshall D. Lindheimer and Dr. Donald F. Steiner gave valuable advice in the preparation of this manuscript. This work was supported in part by grants AM 13601 and AM 13941 from the National Institutes of Health, U. S. Public Health Service, and by grants from the Chicago and Illinois Heart Associations and the Schweppe Foundation of Chicago.

\section{REFERENCES}

1. Gorden, P., and J. Roth. 1969. Plasma insulin: fluctuations in the "Big" insulin component in man after glucose and other stimuli. J. Clin. Invest. 48: 2225.

2. Melani, F., A. H. Rubenstein, and D. F. Steiner. 1970. Human serum proinsulin. J. Clin. Invest. 49: 497.

3. Melani, F., A. H. Rubenstein, P. E. Oyer, and D. F. Steiner. 1970. Identification of proinsulin and C-peptide in human serum by a specific immunoassay. Proc. Natl. Acad. Sci. U. S. A. 67: 148.

4. Rubenstein, A. H., M. Mako, D. F. Steiner, D. Brown, and T. N. Pullman. 1970. The renal extraction and excretion of proinsulin. J. Lab. Clin. Med. 76: 868 .

5. Stoll, R. W., J. L. Touber, L. C. Winterscheid, J. W. Ensinck, and R. H. Williams. 1971. Hypoglycemic activity and immunological half-life of porcine insulin and proinsulin in baboons and swine. Endocrinology. 88: 714.

6. Izzo, J. L., A. Roncone, and M. J. Izzo. 1971. Disposition of I ${ }^{131}$-proinsulin. Diabetes. 20 (Suppl. 1) : 333.

7. Stoll, R. W., J. L. Touber, L. A. Menahan, and R. H. Williams. 1970. Clearance of porcine insulin, proinsulin and connecting peptide by the isolated rat liver. Proc. Soc. Exp. Biol. Med. 133: 894.

8. Rubenstein, A. H., L. A. Pottenger, M. Mako, G. S. Getz, and D. F. Steiner. 1972. The metabolism of proinsulin and insulin by the liver. J. Clin. Invest. 51: 912.

9. Challoner, D. R. 1971. Degradation of porcine insulin and proinsulin by rat adipose tissue. Diabetes. 20: 276.

10. Brush, J. S. 1971. Purification and characterization of a protease with specificity for insulin from rat muscle. Diabetes. $20: 140$.

11. Izzo, J. L., A. Roncone, and M. J. Izzo. 1971. Degradation of ${ }^{131} \mathrm{I}$-insulin by rat liver, kidney and muscle extracts. Fed. Proc. 30: 193.

12. Burghen, G. A., A. E. Kitabchi, and J. S. Brush. 1972. Characterization of a rat liver protease with specificity for insulin. Endocrinology. $91: 633$.

13. Kitabchi, A. E., and F. Stentz. 1972. Degradation of insulin and proinsulin by various organ homogenates of rat. Diabetes. 21 : 1091.

14. Freychet, P., J. Roth, and D. M. Neville. 1971. Insulin receptors in the liver: specific binding of ${ }^{205} \mathrm{I}$-insulin to the plasma membrane and its relation to insulin bioactivity. Proc. Natl. Acad. Sci. U. S. A. 68: 1833.

15. Steiner, D. F., O. Hallund, A. H. Rubenstein, S. Cho, and C. Bayliss. 1968. Isolation and properties of proinsulin, intermediate forms, and other minor components from bovine insulin. Diabetes. $17: 725$ 
16. Steiner, D. F., S. Cho, P. E. Oyer, S. Terris, J. D. Peterson, and A. H. Rubenstein. 1971. Isolation and characterization of proinsulin and C-peptide from bovine pancreas. J. Biol. Chem. 246: 1365.

17. Davidson, W. D., and M. A. Sackner. 1963. Simplification of the anthrone method for determination of inulin in clearance studies. J. Lab. Clin. Med. 41: 351.

18. Smith, H. W., N. Finkelstein, L. Aliminosa, B. Crawford, and M. Graeber. 1945. The renal clearance of substituted hippuric acid derivatives and other aromatic acids in dog and man. J. Clin. Invest. 24: 388.

19. Huggett, A. St., G., and D. A. Nixon. 1957. Use of glucose oxidase, peroxidase and o-dianisidine in determination of blood and urinary glucose. Lancet. 2: 368.

20. Morgan, C. R., and A. Lazarow. 1963. Immunoassay of insulin: two antibody system. Plasma insulin levels of normal, subdiabetic and diabetic rats. Diabetes. 12: 115.

21. Tait, J. F. 1963. Review: The use of isotopic steroids for the measurement of production rates in vivo. $J$. Clin. Endocrinol. Metab. 23: 1285.

22. Mashiter, K., and T. M. King. 1969. Changes of immunoreactivity of proinsulin induced by rat tissue extracts. Nature (Lond.). 224: 696.

23. Izzo, J. L., J. W. Bartlett, A. Roncone, M. J. Izzo, and W. F. Bale. 1967. Physiological processes and dynamics in the disposition of small and large doses of biologically active and inactive ${ }^{131}$ I-insulin in the rat. $J$. Biol. Chem. 242: 2342.

24. Silvers, A., R. S. Swenson, J. W. Farquhar, and G. M. Reaven. 1969. Derivation of a three compartment model describing disappearance of plasma insulin- ${ }^{131} \mathrm{I}$ in man. J. Clin. Invest. 48: 1461.

25. Stern, M. P., J. W. Farquhar, A. Silvers, and G. M. Reaven. 1968. Insulin delivery rate into plasma in normal and diabetic subjects. J. Clin. Invest. 47: 1947.

26. Orskov, H., and N. J. Christensen. 1969. Plasma disappearance rate of injected human insulin in juvenile diabetic, maturity-onset diabetic, and nondiabetic subjects. Diabetes. 18: 653 .

27. Corvilain, J., H. Brauman, C. Delcroix, C. Toussaint, P. Vereerstraeten, and J. R. M. Franckson. 1971. Labeled insulin catabolism in chronic renal failure and in the anephric state. Diabetes. 20: 467.

28. Ooms, H. A., Y. Arnould, U. Rosa, G. F. Pennisi, and J. R. M. Franckson. 1968. Clearances métaboliques globales de l'insuline cristalline et d'insulines substituées au radioiode. Pathol. Biol. 16: 241.

29. Swenson, R. S., A. Silvers, D. T. Peterson, S. Kohatsu, and G. M. Reaven. 1971. Effect of nephrectomy and acute uremia on plasma insulin- ${ }^{125} \mathrm{I}$ removal rate. J. Lab. Clin. Med. $77: 829$.
30. Tompkins, C. V., M. C. Srivastava, P. H. Sonksen, and J. D. N. Nabarro. 1971. A comparative study of the distribution and metabolism of monocomponent human insulin and porcine proinsulin in man. Biochem. J. 125: 64.

31. Starr, J. I., A. Katz, D. F. Steiner, and A. H. Rubenstein. 1972. Metabolism of endogenous proinsulin in man. Diabetes. 21 (Suppl. 1) : 347.

32. Mirsky, I. A., and R. H. Broh-Kahn. 1949. The inactivation of insulin by tissue extracts. I. The distribution and properties of insulin inactivating extracts (insulinase). Arch. Biochem. 20: 1.

33. Darmady, E. M. 1965. Correlation of renal function and structure. J. Clin. Pathol. 18: 493.

34. Narahara, H. T., N. B. Everett, B. S. Simmons, and R. H. Williams. 1958. Metabolism of insulin- $\mathrm{I}^{131}$ and glucagon $\mathrm{I}^{131}$ in the kidney of the rat. Am. J. Physiol. $192: 227$.

35. Melick, R. A., and T. J. Martin. 1969. Parathyroid hormone metabolism in man: effect of nephrectomy. Clin. Sci. 37: 667 .

36. Clendinnen, B. G., W. D. Davidson, B. M. Jackson, and J. C. Thompson. 1970. Renal inactivation of gastrin. Br.J.Surg. 57: 864.

37. Bernier, G. M., and M. E. Conrad. 1969. Catabolism of human $\beta_{2}$-microglobulin by the rat kidney. Am. J. Physiol. $217: 1359$.

38. Bailie, M. D., F. C. Rector, Jr., and D. W. Seldin. 1971. Angiotensin II in arterial and renal venous plasma and renal lymph in the dog. J. Clin. Invest. 50: 119.

39. Chamberlain, M. J., and L. Stimmler. 1967. The renal handling of insulin. J. Clin. Invest. 46: 911.

40. Rabkin, R., N. M. Simon, S. Steiner, and J. A. Colwell. 1970. Effect of renal disease on renal uptake and excretion of insulin in man. N. Engl. J. Med. 282: 182.

41. Rabkin, R., and J. A. Colwell. 1969. The renal uptake and excretion of insulin in the dog. J. Lab. Clin. Med. 73: 893 .

42. Zaharko, D. S., L. V. Beck, and R. Blankenbaker. 1966. Role of the kidney in the disposal of radioiodinated and nonradioiodinated insulin in dogs. Diabetes. 15: 680 .

43. Rubenstein, A. H., C. Lowy, T. A. Welborn, and T. R. Fraser. 1967. Urine insulin in normal subjects. Metab. (Clin. Exp.). 16: 234.

44. Berson, S. A., and R. S. Yalow. 1970. Plasma insulin. In Diabetes Mellitus: Theory and Practice. M. Ellenberg and H. Rifkin, editors. McGraw-Hill, Inc., New York. 308

45. Graham, R. C. Jr., and M. J. Karnovsky. 1966. Glomerular permeability. Ultrastructural cytochemical studies using peroxidases as protein tracers. J. Exp. Med. 124: 1123. 